\title{
Opis użycia słów i gestów w komunikacji - perspektywa użytkownika języka a perspektywa badacza specjalisty
}

Słow a klucze: słowo; gest; komunikacja; powiedzieć, pokazać; terminologia

Ke y w ord s: word; gesture; communication; to say; to show; terminology

Percepcja zjawisk językowych badaczy specjalizujących się w analizach tych zjawisk i laików odnoszących się do tych zjawisk na co dzień za pomocą wyrażeń języka ogólnego, ale nieznających metajęzyka specjalistycznego, jest różna ${ }^{1}$ I tak na przykład użytkownik języka nazwie wskazywaniem wykonanie tylko niektórych gestów z tych, które lingwiści w ramach swoich badań kwalifikuja jako gesty wskazywania (na temat tych różnic w języku ogólnym i specjalistycznym pisałam w artykule Heliasz-Nowosielska 2016b).

${ }^{1}$ Moim zdaniem, trudność pracy lingwisty wynika właśnie z konieczności godzenia ze sobą dwóch ról: użytkownika metajęzyka ogólnego i użytkownika metajęzyka specjalistycznego, i związanych z tymi rolami dwóch różnych perspektyw, z których można przyglądać się analizowanym zjawiskom. Podobnie jak np. L. Fleck (1986) uważam, że laik inaczej pojmuje zjawiska, z którymi się styka, i używa w odniesieniu do nich innych słów niż specjalista (dotyczy to nie tylko obiektów badań lingwistycznych, por. np. Radford 2002). Tę tezę potwierdzają, według mnie, m.in. analizy porównawcze przeprowadzone w pracy Heliasz-Nowosielska (2016b) i w niniejszym artykule. 
Podobnie rzecz się ma z kwalifikacjami użycia słów i gestów za pomocą wyrażeń z ciągami powiedz(')-, mów(')- i pokaz-2: zakres tych wyrażeń w języku ogólnym jest inny niż zakres terminów w języku specjalistycznym nawiązujących swoją formą do tych wyrażeń.

Celem niniejszego artykułu jest wskazanie różnic między zakresami wyrażeń języka ogólnego a wybranymi terminami specjalistycznymi opisującymi użycia słowa i gestu w komunikacji. Różnice te ujawniła analiza tekstów użytkowych i specjalistycznych związanych z interesującym mnie tu tematem. Analiza zostanie w tym miejscu ograniczona do wybranych aspektów sygnalizowanego problemu (próbę wyczerpującego opisu stanowi przygotowywana przez mnie książka). Wiele ciekawych wątków pozostanie więc poza zakresem tego artykułu, $\mathrm{m}$. in. nie będę analizować tu opisów słownikowych omawianych wyrażeń, a jedynie związane z tymi wyrażeniami teksty naukowe; odniosę się wyłącznie do opisów gestów stosowanych przez ogół mówiących, pominę sprawę opisów użyć znaków języka migowego; nie przedstawię tu także typologii czasowników nazywających akty mowy ze względu na ich odniesienie do użycia słów lub gestów. Tematom tym zamierzam poświęcić uwagę w osobnych opracowaniach.

\section{Opozycja użycia słowa i gestu w języku ogólnym}

Analiza wypowiedzi użytkowników języka ogólnego wykazuje, że językowo istotne jest to, czy przekazywanie sobie nawzajem wiadomości odbywa się w formie ustnej czy pisemnej, za pomocą słów czy za pomocą gestów. Jeśli na przykład Maria od dłuższego czasu bezskutecznie przeszukuje mieszkanie w celu odnalezienia swojego segregatora, może w którymś momencie zwrócić się do Jana z pytaniem: Nie widziałeś przypadkiem mojego segregatora...? Jan może na takie pytanie zareagować, używając albo słów, albo gestów, albo jednego i drugiego. W zależności od tego, w jaki sposób przekaże on Marii wiadomość, dotyczącą miejsca, w którym znajduje się poszukiwany przez nią segregator, Maria będzie mogła zdać sprawę z faktu otrzymania

2 Świadomie nie stawiam tu problemu delimitacji jednostek języka z ciągami powiedz(')-, mów(')- i pokaz- i nie prezentuję swoich ustaleń w tym zakresie. Ze względu na cele i zakres tego artykułu ograniczam się do przedstawienia kontrastów między użyciami wyrażeń z każdym z interesujących mnie ciągów w kontekstach ogólnojęzykowych i specjalistycznych. 
tej informacji za pomocą jednego - nie dowolnego (!) - z poniższych stwierdzeń:

(1) Powiedział mi, gdzie leży segregator.

(2) Powiedziat mi, że segregator leży na górnej półce obok encyklopedii.

(3) Pokazat mi (palcem) segregator na górnej pótce obok encyklopedii.

(4) Pokazat mi (palcem), gdzie leży segregator.

(5) Pokazał mi (palcem), że segregator leży na górnej pótce obok encyklopedii.

(6) Napisat mi, gdzie leży segregator.

(7) Napisał mi, że segregator leży na górnej pótce obok encyklopedii.

Każda z tych relacji zostanie inaczej zrozumiana przez odbiorcę: (1) - (2) jako odnosząca się do użycia słowa mówionego, (3) - (5) - użycia gestu, (6) - (7) - użycia słowa pisanego.

Za pomocą gestu Jan mógł przekazać Marii informację o położeniu segre-

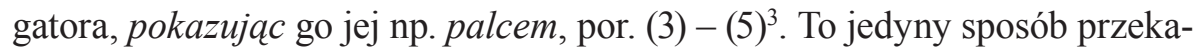
zania tej informacji przez Jana, który pozwala Marii przekonać się na własne oczy, że segregator znajduje się na górnej półce obok encyklopedii. Oczywiście, Jan, pokazujac Marii segregator, może coś powiedzieć, ale z tej jego czynności wypowiedzi (3) - (5) nie zdają sprawy. Jan mógł też ograniczyć się do ustnego przekazania Marii informacji o położeniu segregatora, czyli

${ }^{3}$ Konteksty te różnią się od kontekstów takich jak np. W wystapieniu pokazat, że warto kierować się miłościa bliźniego., które nie dopuszczają uzupełnienia o nazwę narzędzia - ani gestycznego, por. W wystapieniu pokazat *palcem, że warto kierować się miłościa bliźniego., ani słownego czy głosowego, por. W wystapieniu pokazat *słowe$m /{ }^{*}$ głosem, że warto kierować się miłościq bliźniego. Pozostając wiernym wykładni języka ogólnego, nie można stwierdzić, że w tym wypadku coś jest pokazywane za pomocq stów, a nie za pomocq gestów. Samo takie sformułowanie ma już charakter regulacji terminologicznej i stanowi dla mnie dowód na to, że lingwiści, tworząc swój metajęzyk, przekraczają konwencje języka ogólnego dotyczące łączliwości słów i w ten sposób modyfikują zakres analizowanych wyrażeń. Użyty w testowanym kontekście czasownik nie odnosi się, moim zdaniem, do oddziaływania ruchem ciała (czy zastępującego je narzędzia) na zmysły odbiorcy, ale bezpośrednio na jego intelekt. Pozornie percepcyjny charakter mają też inne wyrażenia, np. te, których można byłoby użyć, aby opisać efekty osiągnięte przez mówcę dzięki pokazaniu znaczenia miłości bliźniego w swoim wystąpieniu, por. np.: Po jego wystapieniu zobaczyli/widzieli/stało się dla nich widoczne, że warto kierować się miłościa bliźniego. 
do powiedzenia jej, gdzie on leży, z czego sprawę zdają konteksty (1) - (2). Zarówno Maria, jak i Jan mogli też w sprawie segregatora porozumieć się za pomocą e-maila, chatu czy SMS-a. Tylko w takim wypadku działania Jana można zrelacjonować za pomocą czasowników z ciągiem napis-, por. np. (6) - (7).

Warto również zauważyć, że o Janie można powiedzieć, że pokazał Marii segregator na półce, skoro sama nie mogła go znaleźć, ale nie można by o nim powiedzieć, że go jej w takiej sytuacji wskazat, bo to miałoby zastosowanie tylko, jeśli Maria nie umiałaby odróżnić segregatora od innych rzeczy na półce, np. teczek, por. Heliasz-Nowosielska (2016b). Ponadto, ze względu na tę właśnie opozycję znaczeniową, tylko pokazać, że_ może zostać użyte w relacji z działań służących dostarczeniu komuś dowodów na potwierdzenie swoich słów - wskazać, że_w takich kontekstach nie występuje, por. np. akceptowalne i nieakceptowalne reakcje na wypowiedź - Nie widzę tego segregatora na tej półce, co mówiłeś...:

(8) - Chodź, pokażę ci, gdzie stoi... vs. - Chodź, wskażę ci, gdzie stoi...

(9) - Chodź, pokaże ci, że tam stoi... vs. - *Chodź, wskaże ci, że tam stoi...

Jeśli z kolei chodzi o odniesienie się do słowa pisanego, to mówiący mogą opisywać jego użycie, posługując się nie tylko czasownikami z kształtem napisać, lecz także czasownikami z ciągami powiedz'- i pokaz'-, włączonymi w kontekst w pewien - w wypadku każdego z tych czasowników inny - sposób, por.:

(10) Konsultant powiedział mi na czacie, że zgodnie z regulaminem mam 14 dni na odstapienie od umowy.

(11) Konsultant pokazal mi punkt regulaminu dotyczacy 14-dniowego okresu odstapienia od umowy.

(12) Konsultant pokazat mi w regulaminie, że mam 14 dni na odstapienie od umowy.

(13) Konsultant napisat mi, że zgodnie z regulaminem mam 14 dni na odstapienie od umowy. 
Zgodnie z konwencją języka ogólnego ktoś, kto powiedziat komuś, że ma 14 dni na odstapienie od umowy, użył głosu i słów; ktoś, kto pokazał komuś punkt w regulaminie, użył gestu i odniósł się za jego pomocą do tekstu pisanego; ktoś, kto napisat komuś, że ma 14 dni na odstąpienie od umowy, użył jednego z nośników wiadomości tekstowych. Kontekstu (10) nie sposób byłoby więc zrozumieć jako odnoszącego się do innej niż ustna formy wymiany informacji, gdyby występujący w nim czasownik z ciągiem powiedz'- nie został wzbogacony o dodatkową charakterystykę wprowadzoną przez określenie miejsca wymiany informacji: na czacie. To miejsce w zdaniu mogą zajmować też inne nazwy tekstów pisanych, np. w liście, w mailu, w ksiażce. Nie ma tu jednak pełnej dowolności, por. np.:

(14) Urzędnik pokazat na kartce, że mamy jeszcze 100 batów zapłacić za wydanie wizy.

(15) Urzędnik napisat na kartce, że mamy jeszcze 100 batów zapłacić za wydanie wizy.

(16) *Urzędnik powiedziat na kartce, że mamy jeszcze 100 batów zapłacić za wydanie wizy.

Określeniem miejsca nie może więc być nazwa nośnika tekstu pisanego, na co wskazują także inne połączenia, por.: napisał na/w pocztówce vs. *powiedział na/w pocztówce, napisat w SMS-ie vs. *powiedziat w SMS-ie, napisat w/na ulotce vs. *powiedziat w/na ulotce, napisat na opakowaniu vs. *powiedziat na opakowaniu.

Połączenia takie jak powiedzieć coś na czacie czy powiedzieć coś w liście są charakterystyczne dla tekstów pisanych. W codziennej komunikacji dominują formy syntetyczne - powiedzieć lub napisać. Zdarza się przy tym, że nadawca, mówiąc o tekście pisanym, używa czasownika powiedzieć i jednocześnie np. potrząsa przed odbiorcą książką czy też wskazuje palcem pismo leżące na stole. W rezultacie otrzymujemy słowno-ruchowy ekwiwalent fraz typu powiedzial w [czymś].

Połączenia napisat kartce czy napisat $w$ sprawozdaniu w porównaniu z samym napisat dostarczają bardziej precyzyjnej charakterystyki nośnika lub typu tekstu. Z kolei wyrażenia takie jak pokazał (palcem) na kartce czy pokazat (palcem) w regulaminie nie różnią się od samego pokazat - odnoszą się standardowo do wykonania gestu, z tym że obiektem odniesienia 
opisywanego przezeń gestu staje się w tym wypadku materialny nośnik z odpowiednim tekstem, np. kartka $\mathrm{z}$ informacją o wysokości opłaty wizowej. W relacjach z obserwowanych zdarzeń użycia słów i gestów są traktowane jako osobne działania: można coś pokazać, a nie powiedzieć, można też coś powiedzieć, a nie pokazać, por. np.:

(17) Zagadniety $w$ tej kwestii Adam nie powiedziat nic, tylko pokazat Ilonce coś na elewacji budynku.

(18) Nic nie powiedziat, zamiast tego pokazal mi kartke z napisem „Wiem, że z nimi rozmawiałaś, zabieram ci motocykl. To ostatnie ostrzeżenie".

(19) ... ostatnio jechałam z mężulkiem i nagle zatrzymałam się $i$ wybuchłam na rondzie wściekła, że nie pokazał mi, gdzie mam jechać, tylko powiedziat, że w lewo (ja nigdy tak na szybko nie wiem, gdzie jest lewo, a gdzie prawo)...

(20) Nic mi nie pokazał, tylko powiedziat, że ładnie się rozwija...

Analogicznie wygląda to także w wypadku opisów gestu czy wyrazu twarzy, którym to opisom służą inne, wyspecjalizowane w tym zakresie czasowniki:

(21) Leutnant Ohlsen nic nie powiedziat. Po prostu kiwnat głowa twierdzaco i pomyślat: to coś znacznie gorszego, niż chlew.

(22) Czułam się nieswojo. Zreszta widać było, że Cam także, ale nic nie powiedział, tylko skinat głowa. Uściskałam go pospiesznie, ale dalej nic nie mówit.

(23) Nic nie powiedzial, tylko się uśmiechnat.

(24) O tym, co wy robicie, nic nie można powiedzieć, można tylko zrobić [mówiący pokazuje podniesiony w górę kciuk].

Autorzy wypowiedzi (17)-(24) nie uznają obserwowanych gestów i wyrazów twarzy za wypadki powiedzenia czegoś, wręcz przeciwnie podkreślają, że nadawca nic nie powiedziat - kiwnięcia czy skinienia głową, uśmiechy, gesty stanowią odrębne działania.

Konteksty (17)-(24) różnią się od nieprecyzyjnych, emotywnych użyć konstrukcji nic nie powiedział, takich jak np.: 
(25) Tusk nic nie powiedziat, tylko atakowat opozycję.

(26) Zaczęłam krzyczeć, że zapłacę, żeby tylko zrobili mi cesarkę. A on nic nie powiedziat, tylko kazał mi taka maskę na twarz założyć z rurkami. Nie wiem, co tam było, chyba tlen. Nic już mówić nie mogłam.

(27) Tymczasem zdarzyło mi się kilkukrotnie, że żadnej nauki nie było. Nic. Żadnego słowa, żadnego dialogu, żadnego drogowskazu. (...) Brak jakiejkolwiek reakcji - nawet w imię miłosierdzia - jest dla mnie przykry. Czuje, że to nie tak miało być $i$ że czegoś konkretnego mi zabrakto. I pewnie niejeden spowiadajacy się ucieszy, że ksiadz mu nic nie powiedziat, tylko szybko zapukat w konfesjonat.

Tego rodzaju wypowiedzi są rzecz jasna formami metonimicznego skrótu $-\mathrm{z}$ ich kontekstu wynika, że ten, o kim mowa, jednak coś powiedziat. Jako że jednak nie było to nic z tych rzeczy, których oczekiwali odbiorcy (a nie dosłownie nic), to nie wyczerpał danej konwencji, np. pytanie - odpowiedź. Precyzyjnie rzecz ujmując, Tusk nie odpowiedział na zadane mu pytanie, czy też nie powiedział niczego od siebie ${ }^{4}$ - podjął wyłącznie polemikę z oponentami; lekarz asystujący przy porodzie nie ustosunkowat się do prośby pacjentki o przeprowadzenie cesarskiego cięcia - zamiast tego kazał jej założyć maskę i kontynuował działania zgodnie z własnym uznaniem; ksiądz w konfesjonale powiedziat to, do czego zobowiązuje go odpowiednia procedura - wypowiedział słowa formuły spowiedzi - ale nie udzielit od siebie pouczenia.

Ważnymi testami, ujawniającymi niezależność tego, że ktoś coś powiedziat, i tego, że ktoś coś pokazał, są niesprzeczne i nietautologiczne wypowiedzi relacjonujące współwystąpienie obu tych działań. Analizowane czasowniki występują w konstrukcjach z imiesłowem przysłówkowym, których charakterystyczną cechą jest to, że służą zdawaniu sprawy z dwóch lub więcej działań jednoczesnych, por. np.:

(28) Jej tato, nic nie mówiqc, pokazat jej, że ma wejść do pokoju swojej mamy.

(29) Ostatnio, gdy nie mogłam go zrozumieć, podszedt, wziat mnie za ręke, zaprowadzit $w$ miejsce, o które mu chodziło, i pokazujac, powiedziat: „To”.

\footnotetext{
${ }^{4}$ Na temat wyrażenia od siebie jako wykładnika asercji pisał A. Bogusławski (2011).
} 
Konstrukcje mówiqc, pokazał czy pokazujac, powiedziat precyzyjnie zdają sprawę z podjętych przez kogoś działań. W przeciwieństwie do nich konstrukcja *milczqc, powiedziat jest nieakceptowalna - jednoczesne wstrzymanie się od użycia głosu i jego użycie nie jest możliwe

$\mathrm{Na}$ istotność medium głosowego, a także na czynnościowy, fizyczny charakter mówienia (przesądzający o tym, że nie jest to działanie czysto mentalne) wskazują także m.in. takie wyrażenia i konstrukcje relacjonujące mówienie jak: udzielić komuś głosu, zabrać głos na zebraniu, zaczać mówić, skończyć mówić, dlugo/krótko mówić (o tym, że_), powiedzieć coś komuś na ucho, ustyszeć / nie ustyszeć, co ktoś powiedziat, mówić jakimś, np. spokojnym czy radosnym, głosem, por. Heliasz-Nowosielska (2016).

Mimo że zarówno mówienie, jak i pokazywanie ma charakter czynności fizycznej, status każdego z tych działań jest na tyle różny, że nie są one przez użytkowników języka ogólnego utożsamiane. Jeśli ktoś coś komuś pokazat, to niekoniecznie też coś komuś powiedział. Świadectwem tego stanu rzeczy jest brak możliwości użycia czasowników z ciągami pokazać i powiedzieć w konstrukcji z_tym samym_czyskoro_, to_, por. np.:

(30) *Pokazat mi palcem segregator i tym samym powiedziat mi, że segregator stoi na górnej półce obok encyklopedii.

(31) *Skoro pokazat mi palcem segregator, to powiedziat mi, że segregator stoi na górnej półce obok encyklopedii.

VS.

(32) Podpisali umowę z dostawca sprzętu i tym samym rozpoczęli z nim wspótprace.

(33) Skoro podpisali umowe z dostawca sprzętu, to rozpoczęli z nim wspótprace.

${ }^{5}$ Nie budzi natomiast zastrzeżeń posłużenie się rzeczownikiem milczenie jako lewostronnym argumentem nieagentywnego czasownika [coś] powiedziało [cośs [komuś], por. np.: Miat na sobie nowy mundur i na blysk wypolerowane oficerki. Nie odezwat sie stowem, tylko stanat przed niq. Jej milczenie powiedziało mu, że wyglada tak, jak powinien. vs. Miat na sobie nowy mundur i na blysk wypolerowane oficerki. Nie odezwat sie słowem, tylko stanat przed niq. *Milczqc, powiedziała mu, że wyglada tak, jak powinien. 
Brak tożsamości między tym, co jest kwalifikowane za pomocą czasowników z ciągami powiedz(')- i pokaz(')-, ujawnia się także w sytuacjach, w których konieczne jest powtórzenie któregoś z tych działań, por.:

(34) O który segregator chodzi? Powiedz mi jeszcze raz, bo nie ustyszałam, co mówisz... vs. O który segregator chodzi? *Powiedz mi jeszcze raz, bo nie widziałam, co mówisz...

(35) O który segregator chodzi? Pokaż mi jeszcze raz, bo nie widziałam, co pokazujesz... vs. O który segregator chodzi? *Pokaż mi jeszcze raz, bo nie ustyszałam, co pokazujesz... ${ }^{6}$

Konieczność ponownego powiedzenia czegoś może wynikać z tego, że odbiorca nie usłyszał czy nie dosłyszał, co powiedział nadawca, konieczność powtórnego pokazania czegoś - $\mathrm{z}$ tego, że ktoś nie widział wykonywanego gestu (nie spojrzał na nadawcę czy też nie zwrócił uwagi na pokazywany obiekt). Daje tu wyraźnie o sobie znać głosowość mówienia i wizualność pokazywania. Niezależnie od tych różnic istniejące w języku konwencje relacjonowania zdarzeń pozwalają na to, by w opisie jakichś wydarzeń całą sytuację reprezentowało wybrane zdarzenie. Działa tu zwykła zasada metonimicznego skrótu. Pokazywaniu zwykle towarzyszy powiedzenie czegoś, choć możliwe są też sytuacje, w których porozumienie zostaje osiągnięte w milczeniu, np. kiedy do pokoju, w którym siedzi wiele osób, wejdzie nieznajomy, jedna z osób siedzących w głębi pomieszczenia rzuci drugiej pytające spojrzenie, a ta pokaże jej palcem nazwisko nieznajomego na liście spodziewanych tego dnia klientów. Jeśli jednak ktoś coś komuś powiedział i jednocześnie coś pokazał, to całe wydarzenie można zrelacjonować zarówno czasownikiem pokazać, jak i powiedzieć, co widać na przykładzie fragmentu rozmowy $\mathrm{z}$ jednego $\mathrm{z}$ forów internetowych:

(36) Gość (inicjatorka dyskusji): Idę z nim przez miasto, on mi pokazuje, że tam gdzieś $w$ dali idzie para młoda, byli takim matym punktem

${ }^{6}$ Zdanie Pokaż mi jeszcze raz, bo nie ustyszałam, co pokazujesz... nie budzi zastrzeżeń w innym kontekście, mianowicie wtedy, kiedy ktoś, kto pokazywał coś komuś, powiedział przy okazji coś, co nie zostało ustyszane przez osobę, która nie będąc inicjatorem zdarzeń, nie wiedziała, na co ma zwrócić uwagę, więc np. tylko popatrzyła w danym kierunku. 
i ja ich na poczqtku nie zauważyłam, bo byli daleko. Jak myślicie, to ma jakieś znaczenie, że mi ich pokazat? :DD

Clear: No ale nic nie powiedziat? Po prostu pokazat i nikt sie nie odezwat? Ty też nie spytałaś?

Gość (inicjatorka dyskusji): Po prostu powiedziat, że tam jest para młoda, a ja mu powiedziałam, że ma dobry wzrok.

Gość (odpowiadający/-a): W pewnych chwilach w życiu słowa sa zbędne :--D

Inicjatorka dyskusji najpierw opisuje zdarzenie, które ją spotkało, używając tylko czasownika pokazać, a następnie opisuje to samo zdarzenie, używając tylko czasownika powiedzieć. Nie oznacza to, że za każdym razem ma na myśli dokładnie to samo działanie swojego partnera. Podany przez nią opis jest za każdym razem cząstkowy. Nie wiadomo więc, co dokładnie zrobił nadawca, kiedy zauważył parę młodą. Jeśli przyjąć, że np. powiedział: „Ooo, widzę parę młodą, jest tam...” i wykonał gest palcem wskazującym, to pełna relacja z tego zdarzenia mogłaby przybrać np. taką formę narratywną, por.:

(37) Powiedziat mi, że widzi parę młodq i pokazat mi palcem dwoje stojacych $w$ oddali ludzi w strojach ślubnych.

Podsumowując, analiza relacji zdarzeń polegających na użyciu słowa mówionego i gestu wykazuje, że użytkownicy języka ogólnego odróżniają od siebie te dwa działania: jeśli ktoś powiedział coś komuś (użył słów), to zrobił co innego, niż ktoś, kto pokazał coś komuś czymś (użył gestów).

\section{Opozycja użycia słowa i gestu w literaturze przedmiotu}

W polskiej literaturze przedmiotu żywa jest dyskusja nad zakresem terminów związanych z komunikowaniem się za pomocą słów a komunikowaniem się za pomocą innych narzędzi: gestów, wyrazu twarzy czy tonu głosu, por. Kneblewski (1980), Jarmołowicz (2005), Orzechowski (2007). Badacze spierają się m. in. o to, jaki zestaw terminów najcelniej ujmuje podstawę wprowadzanych rozróżnień. W obiegu są m. in. pary takie jak: komunikacja werbalna vs. niewerbalna, komunikacja wokalna vs. niewokalna, komunikacja 
językowa vs. niejęzykowa, komunikacja oralna vs. nieoralna (piśmienna). Zwraca uwagę to, że każda z tych par nawiązuje do pojęć istniejących w języku ogólnym, por. komunikować się za pomoca słów / głosu / języka, komunikować się ustnie. Terminologiczna redukcja tych pojęć wymaga uzasadnienia, a także dostarczenia dowodów swojej funkcjonalności. Tych rzeczy - ze względu na brak odniesienia do języka ogólnego - nie ma w dyskusjach na temat zakresu terminów związanych z technikami komunikacji. W pracach lingwistycznych komunikacja słowna bywa utożsamiana z mówieniem, por. np. Chojak (2006: 11-12). Mówieniem nazywane są też jednak zbiorczo akty komunikacji werbalnej i niewerbalnej, por. Austin (1993 [1962]) i przedstawienie tego problemu w jego pracach zaprezentowane przez Jarmołowicz (2005), przyjmowane także przez A. Bogusławskiego (2008, 2015-2016). Takie ujęcie mówienia jest - w rezultacie regulacji terminologicznych - szersze niż ujęcie ogólnojęzykowe.

Sam czasownik powiedzieć w różnych pracach lingwistycznych uzyskiwał różne definicje, wyróżniano też różną liczbę jego znaczeń i użyć, a także różną liczbę jednostek języka z tym kształtem, por. A. Wierzbicka (1973, 1983, 1986, 1987, 1991), Bojar (1978), E. Wierzbicka (1980), Kozarzewska (1990), Łaziński (1997), Bogusławski (2004, 2005, 2008, 2015-2016), Hentschel, Chachulska (2006), Topolińska (2014). W wymienionych tu pracach szczegółowych nie poświęcano szczególnej uwagi sprawie odniesienia tego czasownika do aktów tzw. komunikacji niewerbalnej. Zwracano natomiast uwagę na to, że użycia czasownika powiedzieć wskazują na wyłącznie foniczną realizację aktów mowy, por. A. Wierzbicka (1991: 11), jak również na to, że informacja o narzędziu w strukturze czasowników mówienia jest relewantna, por. E. Wierzbicka (1980: 42-43). Wysuwano też tezy przeciwne: w ujęciu A. Bogusławskiego (2004, 2005, 2015-2016) w wypadku czasownika powiedzieć, że_medium czy substancja nie jest relewantna. Ten pogląd podzielają m. in. M. Danielewiczowa (2002: 24), M. Wołk (2005: 265, przypis 16, 276).

\section{Teoria czasownika powiedzieć Andrzeja Bogusławskiego}

A. Bogusławski (2005: 143) opisuje mówienie, że_jako w określony sposób zorganizowane działanie (oczywiście, działanie mówiacego) dotyczace wiedzy mówiqcego i słuchacza. Działania tego, zdaniem autora, nie można 
wyprowadzić z jakichkolwiek przygodnych fenomenów empirycznych, co wynika z nieempirycznego, tzn. niezmysłowego, charakteru wiedzy i działania, nieredukowalnych składników Rzeczywistości, konstytuujących „mówienie, że”. Być może właśnie dlatego badacz nie koncentruje się na analizie użyć opisywanego wyrażenia, a zamiast tego - jak sam pisze - pokrótce charakteryzuje właściwości semantyczno-składniowe dwóch wyróżnionych przez siebie jednostek powiedzieć: i powiedzieć, że, a następnie od razu przechodzi do rozważań semantycznych: najpierw podaje definicję funktora powiedział, że_w postaci narracyjnej, por. Bogusławski (2005: 148-149), a następnie przedstawia paralokucję wyrażenia 'powiedział, że', a dokładniej ktoś $a$ powiedzial [ ${ }_{w} t_{u}$ [o kimś $c^{\prime} /$ czymś $c^{\prime}$ ] komuś $b$ / do kogoś $b$, że $p$, którą to paralokucję opatruje legendą, por. Bogusławski (2005: 152-154). Propozycję opisu semantyki „powiedzieć, że_”, przedstawioną przez badacza, trudno skontrastować z materiałem języka ogólnego. Trudno też zweryfikować jej trafność za pomocą testów sprzeczności. Źródłem tych trudności jest według mnie to, że propozycja ta ze względu na swój programowo nieempiryczny charakter stanowi raczej wyraz pewnego poglądu na funkcję języka w Rzeczywistości, niż opisowe przybliżenie znaczenia jednego z polskich czasowników.

Nie znaczy to, że w refleksji A. Bogusławskiego sprawa mówienia dostępnego doświadczeniu została pominięta. Badacz analizuje w swoich pracach konteksty odnoszące się do empirycznie uchwytnych wypadków powiedzenia czegoś. Ponadto na wykładach (wygłoszonych w 2015 i 2016 roku, jak dotąd nieopublikowanych, reprezentowanych jedynie przez handout, z którego pochodzą dalsze cytaty) A. Bogusławski podjął temat „,natury powiedzenia sprawozdawczego”, „rozważanej z punktu widzenia perceptybilno-technicznych okoliczności działań, o jakie w tym wypadku chodzi”. Zdaniem badacza, jeżeli owemu najogólniejszemu reprezentantowi niezbywalnego i fundamentalnego działania mownego, jakim jest wyrażenie powiedzieć, że_, przypiszemy przesqdzenie tego, że $w$ jego denotatach obecny jest wybór określonego medium, tzn. określonej substancji, to odrzucimy stanowczy prymat ,formy” w języku, prymat dopuszczajacy jej powiqzanie $z$, pryncypialnie rzecz ujmujac, dowolną substancja. Powiedzieć, że,, rozumiane zgodnie z definicją zaprojektowaną przez A. Bogusławskiego (2004, 2005), może zdaniem badacza równie dobrze zostać użyte w relacji z tego, że ktoś przekazał komuś daną informację w języku migowym, jak i z tego, że 
przekazał ją w języku angielskim na karteczce. Do zrelacjonowania pierwszego z wymienionych zdarzeń nie można użyć, zdaniem autora, czasownika pokazać, bo „pokazanie czegoś” nie musi angażować użycia żadnego kodu, podczas gdy w opisanej sytuacji chodzi właśnie o użycie określonego kodu migowego. Jak się wydaje, w tym rozumieniu powiedzenie, że_zostaje zrównane z użyciem kodu językowego, którego pewnymi aspektami są forma i substancja. Porównanie tej wykładni z ujęciem ogólnojęzykowym wymaga osobnej uwagi, $\mathrm{m}$. in. ze względu na zaangażowanie w nią terminów naukowych, takich jak „kod”, „forma” i „substancja” (używanych w filozofii czy lingwistyce w sposób nietożsamy z użyciami równokształtnych wyrażeń języka ogólnego), których analiza wykracza poza ramy niniejszego tekstu. Podobnie rzecz się ma, jak to zaznaczałam na wstępie mojego artykułu, ze sprawą użyć języka migowego. W tym miejscu odniosę się więc tylko do sprawy tekstów pisanych takich jak przykładowa karteczka z napisem „Wychodzę" czy z informacją o wysokości opłaty wizowej, por. (14). Chodzi tu więc o teksty, które mogą być pokazywane przez jedną osobę drugiej. Otóż, według mnie, o kimś, kto napisał na karteczce „Wychodzę”, a następnie pokazał tę karteczkę towarzyszowi, nie powie się stuprocentowo idiomatycznie (jak o tym pisze A. Bogusławski), że powiedziat, że wychodzi-powie się, że napisat na karteczce, że wychodzi czy, bardziej potocznie, że pokazat karteczkę, że wychodzi. Czasownik powiedzieć bywa używany w odniesieniu do słowa pisanego, ale - tak jak była o tym mowa wcześniej - takim użyciom towarzyszą albo pewne doprecyzowania słowne dotyczące typu tekstu, ale nie jego materialnego nośnika, por. $w$ swoim liście powiedziat / napisat... vs. *na karteczce / *na papierze / *na murze powiedziat vs. na karteczce / na papierze / na murze napisat, albo sytuacyjne, np. trzymanie $\mathrm{w}$ dłoni przed sobą listu, o którym się mówi. Kiedy takich doprecyzowań brak, domyślnie przyjmuje się, że przedmiotem relacji jest próba porozumienia się za pomocą słowa mówionego. Jeśli więc tak nie jest, relacjonujący muszą liczyć się z koniecznością skorygowania swojego sprawozdania, por. np. - Naprawdę ci to powiedziat? - No nie powiedziat, tylko napisat w e-mailu ${ }^{7}$.

7 Według mnie, jeśli na postawione w tym przykładzie pytanie ktoś zareagowałby, mówiąc: „Tak, jak nie wierzysz, mogę Ci pokazać e-mail.”, to - niezależnie od rozłożenia akcentów - również po takiej replice możliwa byłaby reakcja korygująca pytającego, np. taka: „Skoro możesz mi pokazać e-mail, to raczej ci tego nie powiedział, tylko ci to napisał". 


\section{Badania nad gestami}

We współczesnych badaniach nad wskazywaniem (ang. pointing) konkurują ze sobą teorie ujmujące słowa i gesty jako zjawiska osobne z teoriami ujmującymi słowo i gest jako zjawiska ściśle ze sobą związane. Część badaczy wykazuje, że rola gestów - w przeciwieństwie do słów - jest w komunikacji ograniczona, ponieważ służą one głównie innym procesom, np. znajdowaniu czy przypominaniu sobie słów, por. np. Krauss, Hadar (1999). Karl Bühler w swojej Teorii języka uznaje użycia zaimków wskazujących i gestów wskazujących za równorzędne środki językowej płaszczyzny deiktycznej. Inni badacze uznają słowa i gesty za przejawy jednego procesu myślowego - gesty należą w tym ujęciu do języka ${ }^{8}$ i jako takie współtworzą znaczenie wypowiedzi, por. McNeill (1992), Kendon (2000).

Eksperymenty neurolingwistyczne wykazują, że na poziomie procesów mózgowych słowa i gesty mają ze sobą wiele wspólnego: konkurują w fazie przygotowawczej, ale nakładają się w fazie wykonawczej, por. Levelt et al. (1985), dzielą ten sam system komunikacyjny tak, że gest wzmacnia słowo, a słowo hamuje gest, por. Bernardis, Gentilucci (2006), aktywują te same obszary mózgu, por. Xu et al. (2009). W centrum zainteresowania neurolingwistów z natury rzeczy sytuuje się proces neurologiczny, który odpowiada za produkcję i interpretację komunikatów wokalnych i gestycznych. Wyniki ich badań są więc zasadniczo nieporównywalne $\mathrm{z}$ analizami świadomości językowej użytkowników języka ogólnego. Takie porównania są jednak możliwe w wypadku analiz opisowych gestów, takich jak np. prace Kendona i McNeilla.

Adam Kendon (2000) poświęca tematowi stosunku gestów do języka osobne opracowanie. Badacz podkreśla w nim, że jakkolwiek relację między słowem i gestem można ujmować w różny sposób, nie sposób nie zauważyć, że gesty służą doprecyzowywaniu i rozszerzaniu znaczenia wypowiedzi. Na przykład, z samej wypowiedzi „Wczoraj rano zorientowaliśmy się, że drzwi

${ }^{8}$ Kendona (2000) interesują zasadniczo właśnie związki gestów i języka, a nie mówienia i pokazywania. Podobnie A. Bogusławski „powiedzieć, że” traktuje jako wyrażenie zdające sprawę z użycia języka (zbioru wyrażeń), por. Bogusławski (2005: 140-141), a za narzędzia językowe uznaje całe ciało człowieka, por. Bogusławski (2008: 11). W języku ogólnym ważny jest nie stosunek gestów do języka, ale raczej właśnie opozycja słowa i gestu. 
zostały uszkodzone" nie dowiadujemy się, o którą część drzwi chodzi. Jeśli jednak, tak jak w obserwowanej przez badacza sytuacji, ktoś najpierw powie nam o uszkodzeniu, a potem nam je pokaże, rysując dłońmi w powietrzu prostokąt na wysokości dolnego panelu, otrzymujemy informację bardziej precyzyjną. Kendon zdaje sprawę z obserwowanych zdarzeń w języku ogólnym: zarówno w języku włoskim (w którym porozumiewali się rozmówcy), jak i w języku angielskim (w którym pisze o tym Kendon), i polskim mówienie o drzwiach i pokazywanie części drzwi zostaje rozgraniczone. Jeśli ktoś chciałby powiedzieć, że jeden z rozmówców powiedział, że wczoraj rano zorientowali sie, że dolna część panelu została uszkodzona, to przedstawiłby relację uproszczoną, nieprecyzyjną, taką, którą w wypadku kontrowersji co do tego, co kto powiedział, świadkowie mogliby sprostować. Taki stan rzeczy: $\mathrm{z}$ jednej strony brak precyzji w zdawaniu sprawy z przebiegu zdarzeń, z drugiej strony - możliwość korekty, wskazuje na to, że użytkownicy języka ogólnego odróżniają od siebie użycia słów i gestów, choć nie zawsze decydują się to rozróżnienie uwzględniać w swoich wypowiedziach. Jeśli użytkownik języka ogólnego mówi, że ktoś mu coś powiedział, nie odnosi się do użycia przez tego kogoś gestów. Za ich pomocą mogą zostać przekazane pewne informacje na ten sam temat, o którym była wcześniej mowa, ale są to informacje przekazane niezależnie. Ogólnojęzykowa konwencja opisu użycia słów i gestów różni się więc od propozycji Kendona (2000, 2004), który całość tego, co komunikowane w dowolny sposób, traktuje jako jedno zjawisko i nazywa wypowiedziq.

\section{Badania nad obiektyfikacją wiedzy matematycznej}

Sprawa opozycji słów i gestów wiąże się także z szerokim, interdyscyplinarym problemem reprezentowania wiedzy. Ciekawe studium z tego zakresu, dotyczące reprezentowania wartości liczbowych za pomocą tego, co widziane, powiedziane czy napisane (the seen, the spoken and the written), przedstawia Luis Radford (2002).

Badanie opisane w jego artykule zostało zainspirowane przez reakcję jednego z uczniów na prośbę o wykonanie zadania. Uczniom przedstawiono trzy figury reprezentujące trzy kolejne wartości za pomocą dwóch rzędów okręgów (dokładnie były to kolejno figury złożone z dwóch, trzech i czterech okręgów w górnym rzędzie i odpowiednio czterech, pięciu i siedmiu 
okręgów w dolnym rzędzie). Następnie poproszono ich o zaprojektowanie wyrażenia opisującego liczbę okręgów dla figury $n$. W pierwszym momencie jeden z uczniów, dokładnie obejrzawszy figury na tablicy, mocnym głosem wykrzyknął, że figury $n$ nie ma. Ta reakcja skłoniła badacza do refleksji nad tym, w jaki sposób przedmiotem ludzkiej uwagi czy ludzkiego oglądu stają się obiekty niepostrzegalne zmysłowo, takie jak np. liczby. Autora interesowało także to, w jakim stopniu symbole przybliżają ludziom wiedzę o obiektach matematycznych i jak bardzo tego rodzaju obiekty są utożsamiane z reprezentującymi je symbolami. Radford (2002) przeanalizował dyskusję uczniów, towarzyszącą wykonaniu zadania, i doszedł do wniosku, że zamiast stosować procedury matematyczne, uczniowie, posłużywszy się mową, gestem i pismem, przedstawiali w formie narracyjnej swoje doświadczenia związane z powstawaniem obiektu matematycznego. Jako że poszukiwane wyrażenie liczbowe nie stanowiło obiektu percypowalnego, uczniowie odnosili się do tego, co było dostępne ich postrzeżeniu zmysłowemu, a więc przede wszystkim do postrzeganego zmysłowo obrazu figur złożonych z okręgów. Ten sposób działania wydał się autorowi podobny raczej do twórczości malarza niż do postępowania algebraisty. Z mojego punktu widzenia niewątpliwe jest, że działania uczniów przybrały taką a nie inną formę, ponieważ nie były działaniami specjalistów, wyćwiczonych w stosowaniu procedur algebraicznych, lecz działaniami laików, którzy przedstawione im zadanie potraktowali jako zagadke do rozwiązania i uruchomili niespecjalistyczne procedury kombinowania, znane sobie $\mathrm{z}$ doświadczenia rozwiązywania innych, podobnych zagadek. Procedury i formalizmy algebraiczne, oczywiste dla matematyka, młodym adeptom matematyki były obce. W związku z tym postępowali oni zgodnie z procedurami ogólnymi - „laickimi”, a w swoich rozmowach posługiwali się językiem ogólnym, a nie specjalistycznym. W zapisie ich dyskusji zostały - zgodnie z ogólnojęzykowymi konwencjami zapisu dialogu - osobno odnotowane wypadki posłużenia się przez nich stowem $i$ gestem: wypowiedzi zacytowano, gesty zrelacjonowano, zaznaczono również, kto kiedy zwracał się do kogo, por. np. Francis: ... we just have to choose one of that (pointing to the figures of the pattern); Sylvie: (talking also to Francis) Yes, but look at figure 4 (showing figure \#4 with her hand on the page). It's 5. Przyjęcie niespecjalistycznej perspektywy w opisie eksperymentu zaowocowało tym, że działania uczniów związane z przedstawionymi na obrazku okręgami zostały zakwalifikowane tu tak, jak 
zwyczajnie są kwalifikowane w języku ogólnym, i właśnie jako takie stały się przedmiotem zainteresowania badacza w jego próbie semiotycznego podejścia do problemu obiektyfikacji wiedzy matematycznej. Wnioski z tej próby można według mnie uznać za analogiczne do tych, które wyłaniają się z podjętych przeze mnie w tym artykule - refleksji dotyczących metajęzyka ogólnego i metajęzyka lingwistycznego. Sprowadzają się one do spostrzeżenia kontrastu między specjalistami a niespecjalistami w zakresie sposobów percypowania tych samych zjawisk i sposobów odnoszenia się do nich za pomocą słów i gestów, a w tym wypadku także symboli i obrazów.

\section{Wnioski}

Przeprowadzona analiza porównawcza wykazała, że w języku ogólnym wypadki użycia słów i gestów są opisywane ze pomocą różnych wyrażeń. Wynika z tego, że użytkownicy języka postrzegają użycia słów i użycia gestów jako osobne działania. Tymczasem w języku specjalistycznym uwidacznia się tendencja do uznawania użycia słów i gestów za różne formy tego samego działania, którego zakres reguluje się, tworząc terminy lingwistyczne. Część z tych terminów swoim kształtem nawiązuje do jednostek języka ogólnego, ponieważ jednak nie odpowiada mu zakresem, wywołuje potrzebę dyskusji nad tym, jaki ten zakres być powinien. Jeśli źródło tej potrzeby nie zostaje uświadomione, powstają kolejne terminy (może ich być tyle, ile idiolektów badaczy danego zjawiska). Wyższość tych terminów nad wyrażeniami języka ogólnego nie zostaje wykazana. Dotyczy to zresztą nie tylko omówionych tu pojęć, por. Heliasz-Nowosielska (2016), Heliasz-Nowosielska (2016a). Wysiłkiem wartym zachodu wydaje się więc powiązanie ze sobą analiz zjawisk komunikacyjnych oraz analiz metajęzyka ogólnego i specjalistycznego dotyczącego tych zjawisk. Dzięki temu można byłoby zwiększyć prawdopodobieństwo tego, że praca lingwisty nie będzie polegała tylko na wyregulowaniu na potrzeby danego badania zakresu istniejących w języku nazw lub na wytworzeniu nowych nazw dla tego, co w języku ogólnym ma już swoje nazwy. 


\section{Bibliografia}

Austin J. L., 1993 [1962], Mówienie i poznawanie: rozprawy i wykłady filozoficzne, Warszawa: Państwowe Wydawnictwo Naukowe.

Bachtin M., 1986, Problem gatunków mowy, w: M. Bachtin, Estetyka twórczości stownej, Warszawa: Państwowy Instytut Wydawniczy, s. 348-402.

BARTMiŃSKi J., 2012, Jak opisywać gatunki mowy?, w: A. Burzyńska-Kamieniecka (red.), Jezzyk a kultura, t. 23: Akty i gatunki mowy w perspektywie kulturowej, Wrocław, s. 13-32.

Bernardis P., Gentilucci M., 2006, Speech and gesture share the same communication system, Neuropsychologia 44 (2006), s. 178-190.

BogusŁawski A., 1973, Właściwości pragmatyczne wyrażeń równoznacznych. Projekt schematu, Pamiętnik Literacki LXIV, z. 3, s. 121-151.

Bogusıawski A., 1976, O zasadach rejestracji jednostek języka, Poradnik Językowy 8, s. 356-364.

BogusŁawski A., 1987, Obiekty leksykograficzne a jednostki języka, w: Z. Saloni (red.), Studia z polskiej leksykografii wspótczesnej, t. 2, Białystok: Wydawnictwo Filii UW, s. 115-124.

BogusŁawski A., 1988, Język w słowniku, Wrocław: Ossolineum.

Bogustawski A., 2004, Remarks on Quotative 'saying', Studies in Polish Linguistics 1, s. 29-45.

BogusŁawski A., 2005, Do teorii czasownika powiedzieć, Polonica XXIV-XXV, s. $113-129$.

BogusŁawski A., 2008, Semantyka, pragmatyka. Leksykografa głos demarkacyjny, Warszawa: Wydawnictwo Takt.

BogusŁawski A., 2011, Asercja ma imię - nie jedno, Prace Filologiczne LX, s. 37-48.

BogusŁawski A., 2015-2016, Handouty z niepublikowanych wykładów wygłoszonych w ramach seminarium pt. Studia z filozofii języka.

BoJar B., 1978, Polskie czasowniki dotyczące procesów informacyjnych (Elementy metainformacji w tekstach języka naturalnego), w: J. Siatkowski (red.), Studia językoznawcze. Semantyka i sktadnia. Streszczenia prac doktorskich III, Wrocław: Ossolineum, s. 7-43.

Bublitz W., HüBler A. (red.), 2007, Metapragmatics in use, Amsterdam: John Benjamins.

BÜHLER K., 2004 [1934], Teoria języka: o językowej funkcji przedstawiania, Kraków: TAiWPN Universitas.

Снолак J., 2006, Semantyka i składnia czasowników oznaczajacych reakcje stowne, Warszawa: Wydawnictwa Uniwersytetu Warszawskiego. 
Culpeper J., Haugh M., 2014, Pragmatics and the English Language, London, New York: Palgrave Macmillan.

Danielewiczowa M., 2002, Wiedza i niewiedza. Studium polskich czasowników epistemicznych, Warszawa: Katedra Lingwistyki Formalnej UW.

FleCK L., 1986, Powstanie i rozwój faktu naukowego, Lublin: Wydawnictwo Lubelskie.

Heliasz-Nowosielska C., 2016, Co słychać w głosie? Metapragmatyczne relacje z działań wokalnych, Poradnik Językowy 8, s. 62-74.

Heliasz-Nowosielska C., 2016a, What does to communicate mean? Natural language vs linguistic terminology, w: E. Gutierrez Rubio, E. Kislova, E. Kubicka (red.), Beiträge zum 19. Arbeitstreffen der Europäischen Slavistischen Linguistik (Polyslav), Wiesbaden: Harrassowitz Verlag, s. 91-100.

Heliasz-Nowosielska C., 2016b, Granice interpretacji lingwistycznej w badaniach nad komunikacją niewerbalną, Biuletyn Polskiego Towarzystwa Językoznawczego (w druku).

Hentschel G., Chachulska B., 2006, On the Morphosyntactic Marking of the Addressee with the Polish verba dicendi mówić and powiedzieć: lexical meaning, syntactic meaning, variation, Studies in Polish Linguistics 3, s. 127-146.

JARmoŁowicz E., 2005, Niewerbalne elementy aktów mowy, Investigationes Linguisticae, vol. 12, s. 89-96.

Kendon A., 2000, Language and gesture: Unity or duality?, w: D. McNeill (red.), Language and gesture, Cambridge, UK: Cambridge University Press, s. 47-63.

Kendon A., 2004, Gesture: visible action as utterance, Cambridge: Cambridge University Press.

KneBlewski R.A., 1980, Komunikacja werbalna i niewerbalna w aspekcie filozoficznym. Rozważania metodologiczne w kierunku teorii aktów komunikowania, w: A. Schaff (red.), Zagadnienia socjo- i psycholingwistyki, Wrocław: Ossolineum, s. 237-249.

KozArzewsKa E., 1990, Czasowniki mówienia we współczesnym języku polskim: studium semantyczno-składniowe, Warszawa: Wydawnictwa Uniwersytetu Warszawskiego.

KRAUSS R.M., HADAR U., 1999, The role of speech-related arm/hand gestures in word retrieval, w: R. Campbell, L. Messing (red.), Gesture, speech, and sign, Oxford: Oxford University Press, s. 93-116.

Levelt W.J.M., Richardson G., La Heis W., 1985, Pointing and voicing in deictic expressions, Journal of Memory and Language 24, s. 133-164.

Lucy J.A., 2004, Reflexive Language: Reported Speech and Metapragmatics, Cambridge: Cambridge University.

ŁAZIŃSKi M., 1997, Opozycja czasowników mówić - powiedzieć w języku polskim. Analiza leksykalna i aspektowa, w: R. Grzegorczykowa, Z. Zaron (red.), Se- 
mantyczna struktura stownictwa i wypowiedzi, Warszawa: Wydawnictwo UW, s. $121-147$.

McNeill D., 1992, Hand and Mind: What Gestures Reveal About Thought, Chicago: University of Chicago Press.

Orzechowski S.W., 2007, Komunikacja niejęzykowa a wiarygodność, Lublin: Wydawnictwo UMCS.

RAdFord L., 2002, The Seen, the Spoken and the Written: A Semiotic Approach to the Problem of Objectification of Mathematical Knowledge, Learning of Mathematics 22, $\mathrm{nr}$ 2, s. 14-23.

Silverstein M., 1976, Shifters, Linguistic Categories, and Cultural Description, w: K. Basso, H.A. Selby (red.), Meaning in Anthropology, Albuquerque: UNM Press, s. 11-55.

Silverstein M., 1993, Metapragmatic discourse and metapragmatic function, w: J.A. Lucy (red.), Reflexive language: reported speech and metapragmatics, Cambridge: Cambridge University Press, s. 33-58.

Silverstein M., 2001, The Limits of Awareness, w: A. Duranti (red.), Linguistic Anthropology: A Reader, Malden: Blackwell, s. 382-401.

Topolińska Z., 2014, Krótko mówił, a powiedział wszystko... Czy czasowniki mówić i powiedzieć stanowią parę aspektową?, w: Maiuscula linguistica. Studia in honorem Professori Matthice Grochowski sextuagesimo quinto dedicata, A. Moroz, P. Sobotka, M. Żabowska (red.), Warszawa: BEL Studio, s. 45-51.

WierzBicka A., 1973, Akty mowy, w: Semiotyka i struktura tekstu, M.R. Mayenowa (red.), Wrocław: Ossolineum, s. 201-219.

Wierzbicka A., 1983, Genry mowy, w: Tekst i zdanie, T. Dobrzyńska, E. Janus (red.), Wrocław: Ossolineum, s. 125-137.

WierzBicka A., 1986, Analiza lingwistyczna aktów mowy jako potencjalny klucz do kultury, w: Problemy wiedzy o kulturze, A. Brodzka, M. Hopfinger, J. Lalewicz (red.), Warszawa: Ossolineum, s. 103-114.

Wierzbicka A., 1987, English speech act verbs: A semantic dictionary, Sydney: Academic Press.

WierzBicka A., 1991, Cross-cultural pragmatics: the semantics of human interaction. Berlin: Mouton de Gruyter.

Wierzbicka E., 1980, Walencja czasowników o znaczeniu „mówić”, Prace Filologiczne XXIX, s. 41-48.

WoŁк M., 2005, O znaczeniu wyrażeń ogłoszenie, obwieszczenie, komunikat i zawiadomienie, Polonica XXIV-XXV, s. 259-279.

Xu J., Gannon P. J., Emmorey K., Smith J. F., Braun A. R., 2009, Symbolic gestures and spoken language are processed by a common neural system, Proceedings of the National Academy of Sciences 106(49), s. 20664-20669. 
The description of the use of words and gestures in communication the perspective of the natural language users and the perspective of the researchers

\section{( s u m m a r y )}

In the first part of my paper, I present language data which show that the use of words and the use of gestures are perceived as separate activities, which can be reported, among others, with the Polish verbs powiedzieć coś komuś and pokazać coś komuś czymś. In the second part, I compare the natural language users' perception of the use of words and gestures with other theoretical approaches. Finally, I come to the conclusion that the natural language users perceive the use of words and gestures differently than the researchers who extend the scope of the natural terms describing the use of words to include the use of gestures. 
